\title{
Chemical Constituents from Solenostemma argel and their Cholinesterase Inhibitory Activity
}

\author{
Rym Gouta Demmak ${ }^{1,2, *}$, Simon Bordage ${ }^{2}$, Abederrahmane Bensegueni ${ }^{1}$, Naima Boutaghane ${ }^{3}$, Thierry Hennebelle ${ }^{2}$, \\ El Hassen Mokrani ${ }^{1}$, and Sevser Sahpaz ${ }^{2}$ \\ ${ }^{I}$ Laboratoire de Biochimie Appliquée, Département des Sciences de la Nature et de la Vie, \\ Université Frères Mentouri-Constantine 1; 25000 Constantine, Algeria \\ ${ }^{2}$ Laboratoire de Pharmacognosie, Univ. Lille, EA 7394 - ICV - Institut Charles Viollette; F-59000 Lille, France \\ ${ }^{3}$ Laboratoire d'Obtention des Substances Thérapeutiques (LOST), Campus Chaabet-Ersas, Département de chimie, \\ Université des Frères Mentouri-Constantine; 25000 Constantine, Algeria
}

\begin{abstract}
Alzheimer's disease is a chronic neurodegenerative disorder with no curative treatment. The commercially available drugs, which target acetylcholinesterase, are not satisfactory. The aim of this study was to investigate the cholinesterase inhibitory activity of Solenostemma argel aerial part. Eight compounds were isolated and identified by NMR: kaempferol-3-O-glucopyranoside (1), kaempferol (2), kaempferol-3-glucopyranosyl $(1 \rightarrow 6)$ rhamnopyranose $(3)$-hydroxybenzoic acid (4), dehydrovomifoliol (5), 14,15-dihydroxypregn-4-ene-3,20-dione (6), 14,15-dihydroxy-pregn-4-ene-3,20-dione-15 $\beta$-D-glucopyranoside (7) and solargin I (8). Two of them (compounds 2 and 3) could inhibit over $50 \%$ of butyrylcholinesterase activity at $100 \mu \mathrm{M}$. Compound (2) displayed the highest inhibitory effect against acetylcholinesterase (AChE) and butyrylcholinesterase (BChE) with a slight selectivity towards the latter. Molecular docking studies supported the in vitro results and revealed that (2) had made several hydrogen and $\pi$ - $\pi$ stacking interactions which could explain the compound potency to inhibit AChE and BChE.
\end{abstract}

Keywords - Alzheimer's disease, Cholinesterase, Molecular docking, Solenostemma argel

\section{Introduction}

Alzheimer's disease (AD) is a chronic neurodegenerative disorder that is characterized by a deficient cholinergic neurotransmission. ${ }^{1}$ The current treatments use acetylcholinesterase $(\mathrm{AChE})$ inhibitors but these drugs have side effects and bioavailability issues., ${ }^{2,3}$ Therefore, better cholinesterase inhibitors are needed. Work on medicinal plants has led to the isolation of several cholinesterase (ChE) inhibitors such as galantamine and physostigmine. ${ }^{4}$ Other ChE inhibitors were found in the Apocynaceae family such as pregnane glycosides. ${ }^{5}$ Those unusual compounds were also reported in the genus Solenostemma. ${ }^{6}$ Solenostemma argel (Delile) Hayne (Apocynaceae) is a desert plant found in the south of Algeria. ${ }^{7}$ It has been used traditionally to treat various diseases including bronchitis, neuralgia and sciatica. ${ }^{8}$ In addition, previous

\footnotetext{
*Author for correspondence

R. G. Demmak, Laboratoire de Biochimie Appliquée, Département des Sciences de la Nature et de la Vie, Université Frères MentouriConstantine 1;25000 Constantine, Algeria

Tel: +213-31-92-32-22; E-mail: rym.demmak@umc.edu.dz
}

studies reported interesting antimicrobial, antiproliferative and anti-inflammatory activities of this species. ${ }^{6,9,10}$ No cholinesterase inhibitory activity of this plant has been reported. The aim of this study was to investigate the cholinesterase inhibitory activity of the aerial parts of Solenostemma argel by bioguided fractionation to purify and identify active compounds and to test them in vitro and in silico on $\mathrm{AChE}$ and $\mathrm{BChE}$.

\section{Experimental}

General experimental procedures-NMR spectra $\left({ }^{1} \mathrm{H}, 500 \mathrm{MHz} ;{ }^{13} \mathrm{C}, 500 \mathrm{MHz}\right)$ were recorded on a Bruker Advance 500 spectrometer. Mass spectra (HR-ESI-MS) were performed on a PE Sciex API 3000 triple quadrupole mass spectrometer equipped with an ion spray turbo source (Thermo Fisher Scientific Extractive). The HPLC apparatus comprised a Shimadzu SCL-10 Avp pump and an SPD-M20A photodiode detector with an analytical and a preparative RP18 column (Silica Upti-prep Strategy, $250 \mathrm{~mm} \times 22 \mathrm{~mm}$; particle size $5 \mu \mathrm{m}$, Grace, France). 
TLC was performed on silica gel $60 \mathrm{~F}_{254}$ plates (Merck, Darmstadt, Germany) and the absorbance of the reaction was measured using Nest 196 Microplate Spectrostar Nano (BMG Labtech).

Plant materials - Aerial parts of Solenostemma argel were harvested in March 2013 in the area of Djanet (Tassili of N'Ajjers massif; South-East of Algeria). The botanical identification of the plant was done by Dr. Bazri K, Department of Plant Biology, Faculty of Biology and Natural Sciences, University of Frères Mentouri, Constantine, Algeria. A voucher specimen (Sol.2013.31) has been deposited at the Herbarium of Laboratory of Applied Biochemistry, University of Frères Mentouri, Constantine,Algeria.

Extraction and isolation - The fresh plant was dried in the shade and then crushed using an electric blender to obtain a fine powder. $500 \mathrm{~g}$ of the powder were macerated in $\mathrm{MeOH} / \mathrm{H}_{2} \mathrm{O}$ (80:20). This extract was concentrated to dryness and the crude extract $(71.4 \mathrm{~g})$ was suspended in $\mathrm{H}_{2} \mathrm{O}$ and partitioned successively with petroleum ether, $\mathrm{CHCl}_{3}$, EtOAc and $n$-BuOH $(3 \times 500 \mathrm{~mL}$ each $)$, then exhaustively concentrated to yield petroleum ether $(1.2 \mathrm{~g})$, $\mathrm{CHCl}_{3}$ (21.4 g), EtOAc (2.1 g) and $n$-BuOH (31.4 g) extracts.

After a preliminary cholinesterase inhibitory screening of various extracts by bioautography, the chloroform extract was selected for further studies and purification of pure compounds.

The chloroform extract was fractionated through an open column chromatography on silica gel using two gradients: Toluene/EtOAc (0 to $100 \%$ EtOAc) and then EtOAc/MeOH (0 to $100 \% \mathrm{MeOH}$ ). This led to 23 fractions that were all tested with the TLC acetylcholinesterase assay. Among the most active fractions (10 - 19), fraction 17 was submitted to another open column chromatography with a gradient of Heptane/EtOAc of increasing polarity and then EtOAc/MeOH. Two of its active subfractions led to the isolation of two pure compounds (1 and 4) by preparative HPLC. Fractions 10, 13 and 19 were further fractionated by preparative HPLC (C18 column) and eluted with mixtures of water containing $0.1 \%$ formic acid (solvent $\mathrm{A}$ ) and acetonitrile (solvent $\mathrm{B}$ ) at a flow rate of $12 \mathrm{~mL} / \mathrm{min}$. This led to the isolation of compounds 2 and $\mathbf{5}$ from fraction 10, compound $\mathbf{6}$ from fraction 13 and compounds 3, 7 and $\mathbf{8}$ from fraction 19.

Kaempferol-3-O-glucopyranoside (1) - Yellow powder; ${ }^{1} \mathrm{H}-\mathrm{NMR}\left(\mathrm{CD}_{3} \mathrm{OD}\right) \delta$ : $8.08\left(1 \mathrm{H}, \mathrm{d}, J=8.70 \mathrm{~Hz}, \mathrm{H}-2{ }^{\prime}, \mathrm{H}-\right.$ 6'), 6.91 (1 H, d, J=8.70 Hz, H-3', H-5'), 6.43 (1 H, s, H8), $6.22(1 \mathrm{H}, \mathrm{s}, \mathrm{H}-6), 5.72\left(1 \mathrm{H}, \mathrm{d}, J=7.10 \mathrm{~Hz}, \mathrm{H}-1^{\prime \prime}\right)$, 3.91 (1 H, m, H-6"a), 3.73 (1 H, m, H-6"b), 3.56 (1 H, m, H-5"), 3.54 (1 H, m, H-2"), 3.52 (1 H, m, H-3"), 3.44 $\left(1 \mathrm{H}, \mathrm{m}, \mathrm{H}-4^{\prime \prime}\right) .{ }^{13} \mathrm{C}-\mathrm{NMR}\left(\mathrm{CD}_{3} \mathrm{OD}\right) \delta: 165.0$ (C-7), 161.74 (C-5), 157.2 (C-2), 156.9 (C-9), 131.5 (C-3), 122.6 (C$\left.1^{\prime}\right), 115.2$ (C-3', C-5'). HR-ESI-MS (negative ion) $\mathrm{m} / \mathrm{z}$ $447.09430[\mathrm{M}-\mathrm{H}]^{-}\left(\right.$Calcd for $\left.\mathrm{C}_{21} \mathrm{H}_{19} \mathrm{O}_{11}\right)$.

Kaempferol (2) - Yellow powder; ${ }^{1} \mathrm{H}-\mathrm{NMR}\left(\mathrm{CD}_{3} \mathrm{OD}\right)$ $\delta$ : $8.11\left(1 \mathrm{H}, \mathrm{d}, J=8.92 \mathrm{~Hz}, \mathrm{H}-2^{\prime}, \mathrm{H}-6^{\prime}\right), 6.92(1 \mathrm{H}, \mathrm{d}$, $\left.J=8.77 \mathrm{~Hz}, \mathrm{H}-3^{\prime}, \mathrm{H}-5^{\prime}\right), 6.41$ (1 H, s, H-8), 6.20 (1 H, s, $\mathrm{H}-6) .{ }^{13} \mathrm{C}-\mathrm{NMR}\left(\mathrm{CD}_{3} \mathrm{OD}\right) \delta$ : 176.1 (C-4), 164.4 (C-7), 161.14 (C-5), 159.17 (C-9), 156.86 (C-2), 136.2 (C-3), 129.2 (C-2', C-6'), 115.1 (C-3', C-5'), 103.4 (C-10), 98.1 (C-6), 93.1 (C-8). HR-ESI-MS (negative ion) $\mathrm{m} / z$ $285.0406[\mathrm{M}-\mathrm{H}]^{-}\left(\right.$Calcd for $\left.\mathrm{C}_{15} \mathrm{H}_{9} \mathrm{O}_{6}\right)$.

Kaempferol-3-glucopyranosyl-(1 $\rightarrow$ 6)-rhamnopyranose (3) - Yellow powder; ${ }^{1} \mathrm{H}-\mathrm{NMR}\left(\mathrm{CD}_{3} \mathrm{OD}\right) \delta$ : $8.07(1 \mathrm{H}, \mathrm{d}$, $\left.J=9.00 \mathrm{~Hz}, \mathrm{H}-2^{\prime}, \mathrm{H}-6^{\prime}\right), 6.91$ (1 H, d, $J=9.00 \mathrm{~Hz}, \mathrm{H}-3^{\prime}$, H-5'), 6.40 (1 H, s, H-8), 6.20 (1 H, s, H-6), 5.78 (1 H, d, $\left.J=7.10 \mathrm{~Hz}, \mathrm{H}-1^{\prime \prime}\right), 5.25$ (1 H, d, $\left.J=1.3, \mathrm{H}-1^{\prime \prime \prime}\right), 4.01(1 \mathrm{H}$, m, H-2"'), 3.77 (1 H,m, H-6"a), 3.65 (1 H, m, H-2"),3.58 (1 H, m, H-3"'), 3.52 (1 H, m, H-6"b), 3.44 (1 H, m, H5"'), 3.43 (1 H, m, H-3"), 3.35 (1 H, m, H-4", H-4"'), 3.29 (1 H, m, H-5"), 3.44 (1 H, m, H-4"), 0.99 (3 H, d, $\left.J=6.20, \mathrm{H}-6{ }^{\prime \prime \prime}\right) .{ }^{13} \mathrm{C}-\mathrm{NMR}\left(\mathrm{CD}_{3} \mathrm{OD}\right) \delta: 179.3$ (C-4), 165 (C-7), 164.8 (C-5), 159.9 (C-4'), 157.2 (C-2, C-9), 133.3 (C-3), 130.3 (C-2', C-6'), 121.8 (C-1'), 104.8 (C-10), 101.23 (C-1"'), 99.4 (C-1"), 99.3 (C-6), 93.2 (C-8), 78.69 $\left(\mathrm{C}-2^{\prime \prime}\right), 77.5$ (C-3"'), 76.1 (C-4"), $72.6\left(\mathrm{C}-4^{\prime \prime \prime}\right), 71.0$ (C3"), 70.6 (C-2"'), 70.38 (C-5"), 68.9 (C-5"'), 61.23 (C-6"), 16.2 (C-6"'). HR-ESI-MS (negative ion) $m / z 593.1512$ $[\mathrm{M}-\mathrm{H}]^{-}$(Calcd for $\mathrm{C}_{27} \mathrm{H}_{29} \mathrm{O}_{15}$ ).

p-Hydroxybenzoic acid (4) - White powder; ${ }^{1} \mathrm{H}-\mathrm{NMR}$ $\left(\mathrm{CD}_{3} \mathrm{OD}\right) \delta: 7.88(2 \mathrm{H}, \mathrm{d}, J=8.47 \mathrm{~Hz}, \mathrm{H}-2, \mathrm{H}-6), 6.79$ $(2 \mathrm{H}, \mathrm{d}, J=8.47 \mathrm{~Hz}, \mathrm{H}-3, \mathrm{H}-5) .{ }^{13} \mathrm{C}-\mathrm{NMR}\left(\mathrm{CD}_{3} \mathrm{OD}\right) \delta$ : $171.6(\mathrm{COOH}), 161.16$ (C-4), 131.4 (C-2, C-6), 123.8 (C1), 114.41 (C-3, C-5). HR-ESI-MS (negative ion) $\mathrm{m} / \mathrm{z}$ $137.1221[\mathrm{M}-\mathrm{H}]^{-}\left(\right.$Calcd for $\left.\mathrm{C}_{7} \mathrm{H}_{5} \mathrm{O}_{3}\right)$.

Dehydrovomifoliol (5) - Yellow powder; ${ }^{1} \mathrm{H}-\mathrm{NMR}$ $\left(\mathrm{CD}_{3} \mathrm{OD}\right) \delta: 7.02(1 \mathrm{H}, \mathrm{d}, J=15.92 \mathrm{~Hz}, \mathrm{H}-7), 6.46(1 \mathrm{H}$, d, $J=15.92 \mathrm{~Hz}, \mathrm{H}-8), 5.96$ (1 H, m, H-4), 2.63 (1 H, d, $J=17.83 \mathrm{~Hz}, \mathrm{H}-2), 2.33$ (3 H, s, H-10), 1.92 (3 H, d, $J=1.41 \mathrm{~Hz}, \mathrm{H}-13$ ), 1.08 (3 H, s, H-12), 1.03 (3H, s, H11). ${ }^{13} \mathrm{C}-\mathrm{NMR}\left(\mathrm{CD}_{3} \mathrm{OD}\right) \delta$ : 199.30 (C-9), 199.0 (C-3), 163.3 (C-5), 146.97 (C-7), 130.4 (C-8), 126.7 (C-4), 78.53 (C-6), 49.14 (C-2), 41.68 (C-1), 26.21 (C-10), 23.34 (C-12), 22.13 (C-11), 17.74 (C-13). HR-ESI-MS (negative ion) $m / z 221[\mathrm{M}-\mathrm{H}]^{-}\left(\right.$Calcd for $\mathrm{C}_{13} \mathrm{H}_{17} \mathrm{O}_{3}$ ).

14,15-dihydroxy-pregn-4-ene-3,20-dione (6) - White powder; ${ }^{1} \mathrm{H}-\mathrm{NMR}\left(\mathrm{CD}_{3} \mathrm{OD}\right) \delta: 5.74(1 \mathrm{H}, \mathrm{s}, \mathrm{H}-4), 4.45$ $(1 \mathrm{H}, \mathrm{dd}, J=7.55,9.07 \mathrm{~Hz}, \mathrm{H}-15), 2.81(1 \mathrm{H}, \mathrm{dd}, J=4.99$, $10.08 \mathrm{~Hz}, \mathrm{H}-17), 2.50$ (1 H, m, H-2), 2.42 (1 H, m, H16a), 2.34 (1 H, m, H-6a), 2.29 (1 H, m, H-6b), 2.27 (3 H, 
s, H-21), $2.20(1 \mathrm{H}, \mathrm{m}, \mathrm{H}-7 \mathrm{a}), 2.13(1 \mathrm{H}, \mathrm{m}, 1 \mathrm{a}), 1.80$ (1 H, m, H-8), $1.74(1 \mathrm{H}, \mathrm{m}, 1 \mathrm{~b}), 1.70(1 \mathrm{H}, \mathrm{m}, 16 \mathrm{~b}), 1.60$ $(1 \mathrm{H}, \mathrm{m}, 12 \mathrm{a}), 1.58(1 \mathrm{H}, \mathrm{m}, 11 \mathrm{a}), 1.50(1 \mathrm{H}, \mathrm{m}, 12 \mathrm{~b})$, $1.49(1 \mathrm{H}, \mathrm{m}, 7 \mathrm{~b}), 1.48(1 \mathrm{H}, \mathrm{m}, 11 \mathrm{~b}), 1.39(1 \mathrm{H}, \mathrm{m}, \mathrm{H}-9)$, 1.25 (3 H, s, 19), 1.05 (3 H, s, 18). ${ }^{13} \mathrm{C}-\mathrm{NMR}\left(\mathrm{CD}_{3} \mathrm{OD}\right) \delta$ : 217.6 (C-20), 201.3 (C-3), 173.9 (C-5), 123.1 (C-4), 82.0 (C-14), 73.8 (C-15), 60 (C-17), 49.4 (C-9), 40.8 (C-8), 39.0 (C-10), 38.3 (C-12), 36.0 (C-1), 35.1 (C-16), 33.9 (C-6), 33.7 (C-2), 31.6 (C-21), 27.4 (C-7), 21.0 (C-11), 17.3 (C-19), 15.6 (C-18). HR-ESI-MS (negative ion) $\mathrm{m} / \mathrm{z}$ $345.20594[\mathrm{M}-\mathrm{H}]^{-}\left(\right.$Calcd for $\left.\mathrm{C}_{21} \mathrm{H}_{30} \mathrm{O}_{4}\right)$.

14,15-dihydroxy-pregn-4-ene-3,20-dione-15ß-Dglucopyranoside (7) - White powder ; ${ }^{1} \mathrm{H}-\mathrm{NMR}\left(\mathrm{CD}_{3} \mathrm{OD}\right)$ $\delta: 5.74(1 \mathrm{H}, \mathrm{s}, \mathrm{H}-4), 4.30\left(1 \mathrm{H}, \mathrm{d}, J=7.7 \mathrm{~Hz}, \mathrm{H}-1^{\prime}\right), 3.91$ $\left(1 \mathrm{H}, \mathrm{dd}, J=2.20,11.60 \mathrm{~Hz}, \mathrm{H}-6^{\prime} \mathrm{a}\right), 3.58(1 \mathrm{H}, \mathrm{dd}, J=$ 6.96, 11.62, H-6'b), 3.36 ( $\left.1 \mathrm{H}, \mathrm{t}, J=8.72, \mathrm{H}-3^{\prime}\right), 3.26$ ( $\left.1 \mathrm{H}, \mathrm{m}, \mathrm{H}-5^{\prime}\right), 3.20\left(1 \mathrm{H}, \mathrm{d}, J=1.62 \mathrm{~Hz}, \mathrm{H}-4^{\prime}\right), 3.19(1 \mathrm{H}$, d, $\left.J=1.45, \mathrm{H}-2^{\prime}\right), 2.75(1 \mathrm{H}, \mathrm{dd}, J=5.99,9.60 \mathrm{~Hz}, \mathrm{H}-17)$, $2.52(1 \mathrm{H}, \mathrm{m}, \mathrm{H}-2), 2.42(1 \mathrm{H}, \mathrm{m}, \mathrm{H}-16 \mathrm{a}), 2.35(1 \mathrm{H}, \mathrm{m}$, H-6a), 2.29 (1 H, m, H-6b), 2.28 (3 H, s, H-21), 2.17 $(1 \mathrm{H}, \mathrm{s}, \mathrm{H}-7 \mathrm{a}), 2.11(1 \mathrm{H}, \mathrm{m}, 1 \mathrm{a}), 1.80(1 \mathrm{H}, \mathrm{m}, \mathrm{H}-8), 1.74$ ( $1 \mathrm{H}, \mathrm{m}, 1 \mathrm{~b}), 1.70(1 \mathrm{H}, \mathrm{m}, 16 \mathrm{~b}), 1.65(1 \mathrm{H}, \mathrm{m}, 12 \mathrm{a}), 1.58$ $(1 \mathrm{H}, \mathrm{m}, 11 \mathrm{a}), 1.50(1 \mathrm{H}, \mathrm{m}, 12 \mathrm{~b}), 1.49(1 \mathrm{H}, \mathrm{m}, 7 \mathrm{a}), 1.48$ $(1 \mathrm{H}, \mathrm{m}, 11 \mathrm{~b}), 1.24(3 \mathrm{H}, \mathrm{s}, 19), 1.05(3 \mathrm{H}, \mathrm{s}, 18) .{ }^{13} \mathrm{C}-$ NMR ( $\left.\mathrm{CD}_{3} \mathrm{OD}\right) \delta: 215$ (C-20), 201.4 (C-3), 174.1 (C-5), 122.5 (C-4), 100.5 (C-1'), 82.5 (C-14), 77.04 (C-5'), 76.4 (C-15), 76.0 (C-3'), 73.93 (C-2'), 70.73 (C-4'), 61.83 (C6'), 59.69 (C-17), 49.4 (C-9), 40.9 (C-8), 38.77 (C-10), 38.3 (C-12), 36.0 (C-1), 35.28 (C-16), 33.9 (C-6), 33.7 (C-2), 30.2 (C-21), 29.3 (C-7), 20.60 (C-11), 16.89 (C-19), 15.07 (C-18). HR-ESI-MS (positive ion) $\mathrm{m} / z 531.25366$ $[\mathrm{M}+\mathrm{Na}]^{+}\left(\mathrm{Calcd}\right.$ for $\left.\mathrm{C}_{27} \mathrm{H}_{40} \mathrm{O}_{9} \mathrm{Na}\right)$.

Solargin I (8) - White powder; ${ }^{1} \mathrm{H}-\mathrm{NMR}\left(\mathrm{CD}_{3} \mathrm{OD}\right) \delta$ : $7.68\left(1 \mathrm{H}, \mathrm{d}, J=15.80 \mathrm{~Hz}, \mathrm{H}-7^{\prime}\right), 7.22(1 \mathrm{H}, \mathrm{d}, J=1.92$ Hz, H-2'), $7.11\left(1 \mathrm{H}, \mathrm{dd}, J=1.92,8.03 \mathrm{~Hz}, \mathrm{H}-6^{\prime}\right), 6.83$ $\left(1 \mathrm{H}, \mathrm{d}, J=8.03, \mathrm{H}-5^{\prime}\right), 6.78$ (2 H, s, H-2,H-6), $6.69(1 \mathrm{H}$, d, $J=15.76 \mathrm{~Hz}, \mathrm{H}-7), 6.43\left(1 \mathrm{H}, \mathrm{d}, J=15.80 \mathrm{~Hz}, \mathrm{H}-8^{\prime}\right)$, $6.37(1 \mathrm{H}, \mathrm{dd}, J=6.15,15.76 \mathrm{~Hz}, \mathrm{H}-8), 5.23(1 \mathrm{H}, \mathrm{d}$, $\left.J=1.48 \mathrm{~Hz}, \mathrm{H} 1^{\prime \prime \prime}\right), 5.17\left(1 \mathrm{H}, \mathrm{d}, J=7.33 \mathrm{~Hz}, \mathrm{H} 1^{\prime \prime}\right), 4.85$ ( $2 \mathrm{H}, \mathrm{dd}, J=1.06,6.23 \mathrm{~Hz}, \mathrm{H}-9), 4.00\left(1 \mathrm{H}, \mathrm{m}, \mathrm{H}-2^{\prime \prime \prime}\right)$, $3.91(3 \mathrm{H}, \mathrm{s}, \mathrm{OMe}$ at C-3'), $3.87(6 \mathrm{H}, \mathrm{s}, 2 \mathrm{OMe}$ at C-3,5), 3.74 (1 H, m, H6"a), 3.70 (1 H, m, H-2", H-5"), 3.69 (1 H, m, H-3"'), 3.62 (1 H, m, H-6"b) $3.55\left(1 \mathrm{H}, \mathrm{t}, \mathrm{H} 3^{\prime \prime}\right)$, $3.47\left(1 \mathrm{H}, \mathrm{m}, \mathrm{H}-5^{\prime \prime \prime}\right), 3.46\left(1 \mathrm{H}, \mathrm{m}, \mathrm{H}-4^{\prime \prime}\right), 3.35(1 \mathrm{H}, \mathrm{m}, \mathrm{H}-$ $\left.4^{\prime \prime \prime}\right), 1.11$ (3 H, d, $\left.J=6.36 \mathrm{~Hz}, \mathrm{H}-6^{\prime \prime \prime}\right) .{ }^{13} \mathrm{C}-\mathrm{NMR}\left(\mathrm{CD}_{3} \mathrm{OD}\right)$ $\delta: 168.8$ (C-9'), 153.21 (C-3, C-5), 149.33 (C-3'), 148.12 (C-4'), 145.72 (C-7'), 133.49 (C-1), 133.48 (C-7), 132.9 (C-4), 126.43 (C-1'), 122.79 (C-8, C-6'), $115.3\left(\mathrm{C}-5^{\prime}\right)$, 113.99 (C-8'), 110.4 (C-2'), 104.21 (C-2,C-6), 101.13 (C1", C-1"'), 78.6 (C-2"), 78.56 (C-5"), 78.49 (C-3"'), 77.7
(C-3"), 76.1 (C-4"'), 68.43 (C-5"'), 64.64 (C-9), 61.1 (C$\left.6^{\prime \prime}\right), 55.66$ (2 OMe at $\left.\mathrm{C}-3,5\right), 55.5$ (OMe at C-3'), 16.23 (C-6"'). HR-ESI-MS (negative ion) $\mathrm{m} / z$ 693.24048 [M$\mathrm{H}]^{-}\left(\right.$Calcd for $\left.\mathrm{C}_{33} \mathrm{H}_{41} \mathrm{O}_{16}\right)$.

TLC bioautographic assay - To identify the compounds responsible for the cholinesterase inhibitory activity, the method described previously by Yang et al. was used. ${ }^{8}$ Acetylcholinesterase $(500 \mathrm{U})$ was dissolved in $500 \mathrm{~mL}$ of $0.05 \mathrm{M}$ Tris $-\mathrm{HCl}$ buffer at $\mathrm{pH}=7.8$ and $500 \mathrm{mg}$ of Bovine Serum Albumin (BSA) were added to the solution. The stock solution was kept at $4{ }^{\circ} \mathrm{C}$. 1-Naphthyl acetate $(150 \mathrm{mg})$ was dissolved in a mixture of $40 \mathrm{~mL}$ ethanol and $60 \mathrm{~mL}$ distilled water. A solution of Fast Blue B salt $(50 \mathrm{mg})$ in distilled water $(100 \mathrm{~mL})$ was prepared just before use. Samples were applied to a silica gel TLC plate $(10 \times$ $10 \mathrm{~cm}$ ) and migration was conducted with $\mathrm{CHCl}_{3} / \mathrm{MeOH} /$ $\mathrm{H}_{2} \mathrm{O}$ (90:10:1). After complete removal of the solvents, the plate was sprayed with the enzyme and 1-naphthyl acetate subsequently. The TLC plate was then thoroughly dried again before incubation at $37^{\circ} \mathrm{C}$ for $20 \mathrm{~min}$. The plate was laid flat on plastic plugs in a plastic tank containing water, so that the atmosphere was kept humid, but without wetting the plate. Then the solution of Fast Blue Salt was sprayed onto the TLC plate, giving a purple coloration except where the acetylcholinesterase was inhibited (white spots). Galantamine was used as a reference compound.

Microplate assays - Acetylcholinesterase inhibition was determined spectrophotometrically using acetylthiocholine iodide as substrate as described by an Ellman modified method. ${ }^{11}$ In this method, $20 \mu \mathrm{L}$ of an acetylcholinesterase solution (final concentration $0.037 \mathrm{U} / \mathrm{mL}$ in $0.1 \mathrm{M}$ phosphate buffer $\mathrm{pH}$ 7.4) were added to $227.3 \mu \mathrm{L}$ of Ellman's reagent (final concentration of $0.15 \mathrm{mM}$ in $0.1 \mathrm{M}$ phosphate buffer $\mathrm{pH}$ 7.4) and $2.7 \mu \mathrm{L}$ of test compound solutions in DMSO. Then, $20 \mu \mathrm{L}$ of an acetylthiocholine iodide (ATCI) solution solubilized in demineralized water (final concentration $0.22 \mathrm{mM}$ ) were added to initiate the enzymatic reaction. The final assay volume was $270 \mu \mathrm{L}$ in each well. The plate was shaken for $2 \mathrm{~s}$ and the absorbance was measured at $412 \mathrm{~nm}$ after 30 minutes incubation at $25^{\circ} \mathrm{C}$ using a microplate spectrophotometer. For control assays, test compound solutions were replaced by the solvent used in each well, i.e. $1 \%$ DMSO. The butyrylcholine iodide and the butyrylcholinesterase were used as substrate and enzyme respectively for BChE assay, all the other reagents and conditions being the same as for the $\mathrm{AChE}$ assay. Three independent experiments were performed for each compound. Galantamine was used as positive control. The percentage of $\mathrm{ChE}$ inhibition was 
calculated as follows:

$$
\mathrm{I}(\%)=[(\mathrm{Ac}-\mathrm{As}) / \mathrm{Ac}] \times 100 \%
$$

where $\mathrm{Ac}=$ absorbance of the control solution

As $=$ absorbance of the sample

Molecular docking - Molecular docking was performed on most purified compounds (1-3 and 6-8) and galantamine in order to understand their binding interactions with $\mathrm{AChE}$ and $\mathrm{BChE}$ active sites. In this purpose, the Glide 6.3 algorithm, in which the target atoms are fixed and the ligands are flexible, was used. Compounds were built using MarvinSketch, whereas Crystal structures of human $\mathrm{AChE}$ and $\mathrm{BChE}$, at $2.0 \AA$ r resolution, were downloaded from Protein Data Bank (PDB ID: 4M0E and $2 \mathrm{XQF}$ respectively). ${ }^{12,13}$ Only their catalytic chain A was kept and then prepared for docking using VMD software $^{14}$ and Schrodinger's protein preparation wizard. ${ }^{15}$ This wizard served to add all hydrogen atoms and to control the protonation state and the side chains orientations, especially those of catalytic triad residues of AChE and BChE. VMD software allowed defining the binding sites of enzymes by selecting all residues with at least one heavy atom within $6 \AA$ from the ligand of the target crystal structure. Docking calculations were done with default parameters in a stepwise manner with GLIDE Standard Precision (SP). The resulting poses were ranked according to their GlideScore, which was given as binding energy $\Delta \mathrm{G}(\mathrm{kcal} / \mathrm{mol})$; the lowest energy value is considered as the highest binding.

The best docked conformation was selected and analyzed using Maestro software version 11.3 of the Schrödinger suite.

\section{Result and Discussion}

The extracts obtained from the aerial parts of $S$. argel were subjected to enzyme inhibitory assays against AChE and BChE. The chloroform extract was more active than the crude extract against both enzymes (Table 1) and its AChE activity was higher than those recently reported for a species from the same family of $S$. argel (Vinca minor L.). ${ }^{16}$ Therefore, this chloroform extract was chosen for further phytochemical studies. We also confirmed these results with a TLC bioautography assay and revealed several active compounds in the crude extract and the chloroform extract (Fig. 1). Using the same assay during a bio-guided fractionation, we isolated 8 compounds from the chloroform extract (Fig. 2). Their structures were elucidated by spectroscopic methods including NMR (1D and 2D), HR-ESI-MS and by comparison with published data, confirming the proposed structures of kaempferol-3-
Table 1. $\mathrm{IC}_{50}$ values of Solenostemma argel extracts for inhibitory activities on cholinesterase enzymes

\begin{tabular}{lcc}
\hline \hline \multirow{2}{*}{ Extract } & \multicolumn{2}{c}{$\mathrm{IC}_{50}{ }^{a}$} \\
\cline { 2 - 3 } & $\mathrm{AChE}$ & $\mathrm{BChE}$ \\
\hline Crude extract & $0.134 \pm 0.02^{\mathrm{b}}$ & $0.311 \pm 0.08^{\mathrm{b}}$ \\
Petroleum ether extract & $0.176 \pm 0.03^{\mathrm{b}}$ & $0.223 \pm 0.06$ \\
Chloroform extract & $0.021 \pm 0.09^{\mathrm{b}}$ & $0.065 \pm 0.07^{\mathrm{b}}$ \\
Ethyl acetate extract & $0.401 \pm 0.04^{\mathrm{b}}$ & $0.412 \pm 0.32^{\mathrm{b}}$ \\
$n$-Buthanol extract & $0.152 \pm 0.01^{\mathrm{b}}$ & $0.456 \pm 0.16^{\mathrm{b}}$ \\
Galantamine & $1.479 \pm 0.08^{\mathrm{c}}$ & $10.964 \pm 0.14^{\mathrm{c}}$ \\
\hline
\end{tabular}

${ }^{\mathrm{a}} \mathrm{IC}_{50}$ values (mean \pm S.D.) were obtained from a triplicate assay, ${ }^{\mathrm{b}} \mathrm{IC}_{50}$ in $\mathrm{mg} / \mathrm{mL},{ }^{\mathrm{c}} \mathrm{IC}_{50}$ in $\mu \mathrm{M}$

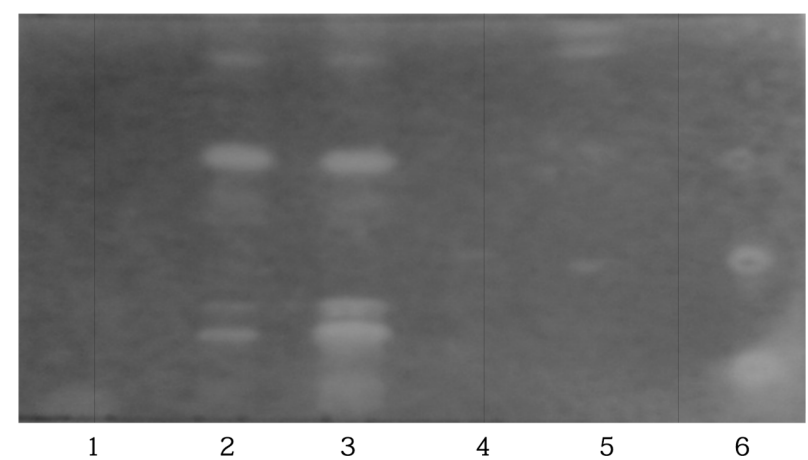

butanol (lane 1), crude extract (lane 2), chloroform (lane 3), ethyl acetate (lane 4) and petroleum ether (lane 5) extracts, and 1, 0.1 and $0.01 \mu \mathrm{g}$ of galantamine (lane 6 , from bottom to top respectively). For lanes $1-5,100 \mu \mathrm{g}$ of dried extracts were separated by TLC before the enzymatic assay.

Fig. 1. Bioautography showing the inhibition of acetylcholinesterase activity.

O-glucopyranoside (1), ${ }^{17}$ kaempferol (2), ${ }^{18}$ kaempferol-3glucopyranosyl-(1 $\rightarrow 6)$-rhamnopyranose $(3),{ }^{19} p$-hydroxybenzoic acid (4), ${ }^{20}$ dehydrovomifoliol (5), ${ }^{21}$ 14,15-dihydroxypregn-4-ene-3,20-dione (6), ${ }^{6}$ 14,15-dihydroxy-pregn-4-ene3,20 -dione-15 $\beta$-D-glucopyranoside (7), ${ }^{6}$ and solargin I $(8)^{22}$ respectively. To our best knowledge, this is the first report of compounds $\mathbf{4}$ and $\mathbf{5}$ in the Apocynaceae family.

Compounds $\mathbf{1}$ - 3 and 6 - 8 were tested on both AChE and BChE with a microplate assay (Table 2). All of them were slightly active ( $>20 \%$ inhibition) on at least one enzyme. We did not have sufficient amounts of compounds $\mathbf{4}$ and $\mathbf{5}$ for the microplate assay. Nevertheless, $p$ hydroxybenzoic acid (4) isolated from an aquatic plant (Nelumbo nucifera) has demonstrated good and noncompetitive $\mathrm{AChE}$ inhibition $\left(\mathrm{IC}_{50}=20.07 \mu \mathrm{M}\right)$ and presented less potent $\mathrm{BChE}$ inhibition $\left(\mathrm{IC}_{50}=62.29 \mu \mathrm{M}\right){ }^{23}$ Furthermore, dehydrovomifoliol (5) isolated from the dichloromethane extract of Gloiopeltis furcata (a marine algae), had a moderate activity on $\mathrm{AChE}\left(\mathrm{IC}_{50}=3.09 \mu \mathrm{g} /\right.$ 
<smiles>[R]Oc1c(-c2ccc(O)cc2)oc2cc(O)cc(O)c2c1=O</smiles><smiles>CC(=O)/C=C/C1(O)C(C)=CC(=O)CC1(C)C</smiles>

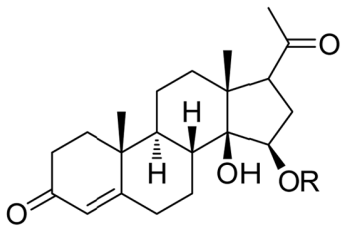

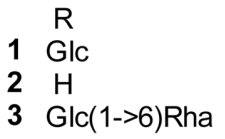

3 Glc $(1->6)$ Rha<smiles>O=C(O)c1ccc(O)cc1</smiles>

4<smiles>COc1cc(/C=C/C(=O)OC/C=C/c2cc(OC)c(OC3OCC(O)C(O)C(O)C3C)c(OC)c2)ccc1O</smiles>

Fig. 2. Structures of compounds $\mathbf{1}-\mathbf{8}$ isolated from Solenostemma argel.

Table 2. Percentage inhibition and binding energy of cholinesterase enzymes by Solenostemma argel isolated compounds

\begin{tabular}{ccccc}
\hline \hline Compound & \multicolumn{2}{c}{ Percentage of inhibition $^{a}$} & \multicolumn{2}{c}{ Binding energy $(\mathrm{Kcal} / \mathrm{mol})^{\mathrm{B}}$} \\
\cline { 2 - 5 } & \multicolumn{1}{c}{ AChE } & BChE & AChE & -7.490 \\
\hline $\mathbf{1}$ & $19.63 \pm 3.76$ & $27.60 \pm 1.80$ & -7.887 & -9.346 \\
$\mathbf{2}$ & $34.28 \pm 2.42$ & $69.51 \pm 2.90$ & -9.869 & -7.780 \\
$\mathbf{3}$ & $8.34 \pm 2.26$ & $51.12 \pm 1.52$ & -7.351 & -6.305 \\
$\mathbf{6}$ & $21.57 \pm 0.55$ & $2.22 \pm 3.05$ & -8.452 & -7.453 \\
$\mathbf{7}$ & $25.38 \pm 4.94$ & $33.01 \pm 7.61$ & -9.004 & -7.254 \\
$\mathbf{8}$ & n.a. & $24 \pm 1.78$ & -6.001 & -10.702 \\
\hline
\end{tabular}

${ }^{\mathrm{a})}$ Values (mean \pm S.D.) were obtained from a triplicate assay using $100 \mu \mathrm{M}$ for each compound tested; compounds $\mathbf{4}$ and $\mathbf{5}$ not tested due to insufficient amount, n.a.: not active.

$\mathrm{mL})$ and a weak activity on $\mathrm{BChE}\left(\mathrm{IC}_{50}=95.08 \mu \mathrm{g} / \mathrm{mL}\right)^{24}$ Together, these results indicate that the phenolic acid (4) and the volatile norisoprenoid (5) could contribute to the ChE inhibitory activity of $S$. argel extracts.

Compounds 6 and 7 were among the most active on AChE, although these activities seemed lower compared to some other pregnanes from plants. For instance, Lee et al. reported that several pregnane glycosides isolated from the roots of Cynanchum atratum (Apocynaceae), cynatroside $\mathrm{A}, \mathrm{B}$ and $\mathrm{C}$, were potent $\mathrm{AChE}$ inhibitors $\left(\mathrm{IC}_{50}\right.$ of $6.4,3.6$ and $52.3 \mu \mathrm{M}$ respectively). ${ }^{4}$ Apart from compound $\mathbf{6}$, all the active compounds were more potent on $\mathrm{BChE}$ compared to AChE. This selectivity in the activity towards the cholinesterase could be attributed, at least in part, to the structural difference of the aromatic gorge of the two enzymes. BChE also inactivates the neurotransmitter $\mathrm{ACh}$ and could be a target for $\mathrm{AD}$ treatment by improving cognition and modulating pathological markers of this disease. ${ }^{24}$ Studies revealed that the $\mathrm{BChE}$ level in specific brain regions is increased with progression of $\mathrm{AD}$ while the $\mathrm{AChE}$ level decreases. ${ }^{25}$ There is currently no $\mathrm{BChE}$ selective inhibitor being employed clinically. ${ }^{26}$ Hence, a BChE selective inhibitor might be useful in the later stages of $\mathrm{AD}$.

Among all the isolated compounds, kaempferol (2) was the most active on both enzymes. Our results are consistent with the percentage of AChE inhibition by kaempferol previously described (percentage of inhibition at $50 \mu \mathrm{M}=14.6) .{ }^{27}$ In addition, Bahrani et al. ${ }^{28}$ tested kaempferol in vitro against $\mathrm{AChE}$ and in vivo in mice and they observed a significant inhibitory activity and an improved memory, respectively. Epidemiological evidence suggests that higher consumption of flavonoids is associated with lower incidence of $\mathrm{AD} .{ }^{29}$ Similarly, S. argel contains multipotent components that might be useful in the treatment of $\mathrm{AD}$. 


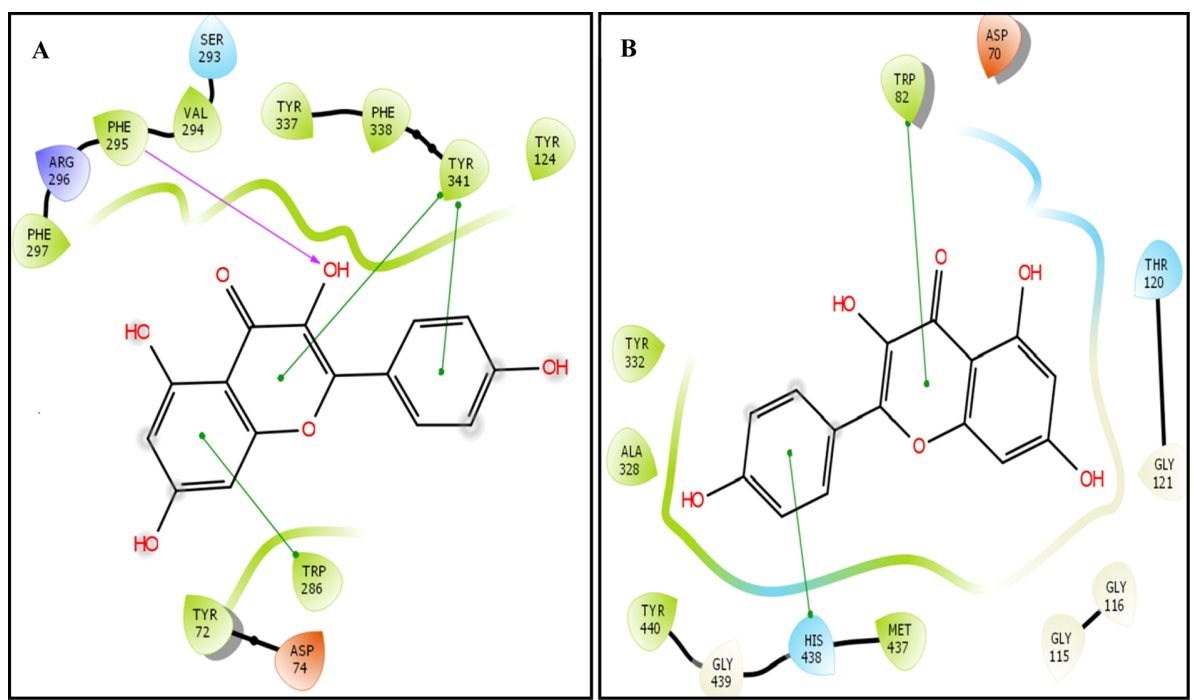

Fig. 3. Binding mode prediction of compound 2 into the entire $\mathrm{AChE}(\mathrm{A})$ and $\mathrm{BChE}(\mathrm{B})$ active pocket. Purple arrows head from the donor to the acceptor of hydrogen bonds and green lines $\pi-\pi$ stackings. The gray circle dimensions are proportional to the accessibility to the solvent.

The molecular docking studies were performed for compounds tested on the microplate assay using the Glide program. The results of molecular docking between enzymes and ligands are shown in Table 2. The experimental data for $\mathrm{ChE}$ inhibitory activities in vitro showed a satisfactory agreement with the molecular docking results (Table 2). Among the tested compounds, $\mathbf{8}$ possessed the lowest free energy of binding against both enzymes (-6.001 for $\mathrm{AChE}$ and -7.254 for $\mathrm{BChE}$ ) while the free energy of binding for compound 2 was the highest (-9.869 for AChE and -9.346 for $\mathrm{BChE}$ ). The most promising inhibitor 2 from in vitro and in silico assays was selected for further investigation of its binding mode into $\mathrm{AChE}$ and $\mathrm{BChE}$ at the active site $3 \mathrm{D}$ space to get insight into the intermolecular interactions using the Glide program. As shown in Fig. 3, compound 2 mainly covers the peripheral site (PAS) in the entrance of $\mathrm{AChE}$ active gorge, making a hydrogen bond with Phe 295 and three $\pi-\pi$ stackings with Tyr 341 and Trp 286. However, this compound covers BChE catalytic site in a rational orientation, making $2 \pi-\pi$ stackings with Trp 82 and His 438, which is considered as a critical member of BChE catalytic triad (Fig. 3). ${ }^{11}$ This interaction with the catalytic site can explain the selectivity of compound 2 towards $\mathrm{BChE}$ instead of $\mathrm{AChE}$ in the in vitro assay.

The bioguided fractionation of $S$. argel extracts led to the isolation of three flavonoids $(\mathbf{1}, \mathbf{2}$ and $\mathbf{3})$, a phenolic acid (4), a norisoprenoid (5), two steroids $(\mathbf{6}, 7)$ and an acylated phenolic glycoside (8). To the best of our knowledge, this is the first report on the cholinesterase inhibitory activity of $S$. argel extracts and of four of its compounds: the original pregnanes14,15-dihydroxy-pregn4ene-3,20-dione (6) and 14,15-dihydroxy-pregn-4-ene3,20-dione-15- $\beta$-D glucopyranoside (7), kaempferol-3glucopyranosyl-( $(1 \rightarrow 6)$-rhamnopyranose $(3)$, and solargin I (8). In addition, all of these compounds were shown or reported to inhibit, at least slightly ( $>20 \%$ ), the activity of one cholinesterase. Among them, two isolated flavonoids (2 and 3) were active on both $\mathrm{AChE}$ and $\mathrm{BChE}$ with a slight specificity for the latter ( $>50 \%$ inhibition). Molecular modeling study confirmed that compound $\mathbf{2}$ showed more potent inhibitory activities than other compounds against both enzymes. Since a dual AChE and BChE inhibitor demonstrates symptomatic efficacy in $\mathrm{AD}$ and flavonoids can be multipotent agents in combating $\mathrm{AD},{ }^{30} \mathrm{~S}$. Argel could deserve further investigation for helping patients with this neurodegenerative disease.

\section{Acknowledgments}

The authors wish to thank the cooperation program between Algeria and France (PROFAS $\mathrm{B}+$ ) for the financial support of this research, and two analytical platforms: LARMN (University of Lille, France, Pr. N. Azaroual) and CUMA (University of Lille, France, Pr. J.F. Goossens) for access to equipment. We are also thankful to the members of these platforms as well as J. Samaillie for their skillful technical assistance.

\section{References}

(1) Machado, L. P.; Carvalho, L. R.; Young, M. C. M.; Cardoso-Lopes, 
E. M.; Centeno, D. C.; Zambotti-Villela, L.; Colepicolo, P.; Yokoya, N. S. Rev. Bras. Farmacogn. 2015, 25, 657-662.

(2) Orhan, I. E.; Orhan, G.; Gurkas, E. Mini Rev. Med. Chem. 2011, 11, 836-842.

(3) Zemek, F.; Drtinova, L.; Nepovimova, E.; Sepsova, V.; Korabecny, J.; Klimes, J.; Kuca, K. Expert Opin. Drug Saf. 2014, 13, 759-774.

(4) Lee, K. Y.; Sung, S. H.; Kim, Y. C. Helv. Chim. Acta. 2003, 86, 474-483.

(5) Kamel, M. S.; Ohtani, K.; Hasanain, H. A.; Mohamed, M. H.; Kasai, R.; Yamasaki, K. Phytochemistry 2000, 53, 937-940.

(6) Ounaissia, K.; Pertuit, D.; Mitaine-Offer, A. C.; Miyamoto, T.; Tanaka, C.; Delemasure, S.; Dutartre, P.; Smati, D.; Lacaille-Dubois, M. A. Fitoterapia 2016, 114, 98-104.

(7) Shafek, R. E.; Shafik, N. H.; Michael, H. N. Asian J. Plant Sci. 2012, 11, 143-147.

(8) Yang, Z.; Zhang, X.; Duan, D.; Song, Z.; Yang, M.; Li, S. J. Sep. Sci. 2009, 32, 3257-3259.

(9) Plaza, A.; Perrone, A.; Balestrieri, C.; Balestrieri, M. L.; Bifulco, G.; Carbone, V.; Hamed, A.; Pizza, C.; Piacente, S. Tetrahedron 2005, 61,7470-7480.

(10) Ibrahim, M. E.; Ahmed, S. S.; El-Sawi, S. A.; Khalid, K. A. J. Essent. Oil Bear. Pl. 2014, 17, 629-632.

(11) Di Giovanni, S.; Borloz, A.; Urbain, A.; Marston, A.; Hostettmann, K.; Carrupt, P. A.; Reist, M. Eur. J. Pharm. Sci. 2008, 33, 109-119.

(12) Cheung, J.; Gary, E. N.; Shiomi, K.; Rosenberry, T. L. ACS Med Chem Lett. 2013, 4, 1091-1096.

(13) Wandhammer, M.; Carletti, E.; Van Der Schans, M.; Gillon, E.; Nicolet, Y.; Masson, P.; Goeldner, M.; Noort, D., Nachon, F. J. Biol.Chem. 2011, 286, 16783-16789.

(14) Humphrey, W.; Dalke, A.; Schulten, K. J. Mol. Graph. 1996, 14, 33-38.

(15) Schrödinger, L. Schrödinger Release 2015-1: Maestro (version 10.1). 2015, N. Y.

(16) Lobbens, E. S.; Vissing, K. J.; Jorgensen, L.; van de Weert, M.;
Jäger, A. K. J. Ethnopharmacol. 2017, 200, 66-73.

(17) Wei, Y.; Xie, Q.; Fisher, D.; Sutherland, I. A. J. Chromatogr. A. 2011, 1218, 6206-6211.

(18) Park, J. S.; Rho, H. S.; Kim, D. H.; Chang, I. S. J. Agric. Food Chem. 2006, 54, 2951-2956.

(19) Budzianowski, J. Phytochemistry 1990, 29, 3643-3647.

(20) Cho, J. Y.; Moon, J. H.; Seong, K. Y.; Park K. H. Biosci. Biotechnol. Biochem. 1998, 62, 2273-2276.

(21) Schievano, E.; Stocchero, M.; Morelato, E.; Facchin, C.; Mammi, S. Metabolomics 2012, 8, 679-690.

(22) Kamel, M. S. Phytochemistry 2003, 62, 1247-1250.

(23) Jung, H. A.; Jung, Y. J.; Hyun, S. K.; Min, B. S.; Kim, D. W.; Jung, J. H.; Choi, J. S. Biol. Pharm. Bull. 2010, 33, 267-272.

(24) Fang, Z.; Jeong, S. Y.; Jung, H. A.; Choi, J. S.; Min, B. S.; Woo, M. H. Chem. Pharm. Bull. 2010, 58, 1236-1239.

(25) Darvesh, S. Curr. Alzheimer Res. 2016, 13, 1173-1177.

(26) Mehta, M.; Adem, A.;Sabbagh, M. Int. J. Alzheimers Dis. 2012, 2012,728983 .

(27) Guo, A. J. Y.; Xie, H. Q.; Choi, R. C. Y.; Zheng, K. Y. Z.; Bi, C. W. C.; Xu, S. L.; Dong, T. T. X.; Tsim, K. W. K. Chem. Biol. Interact. 2010, 187, 246-248.

(28) Bahrani, H.; Mohamad, J.; Paydar, M. J.; Rothan, H. A. Curr. Alzheimer Res. 2014, 11, 206-214.

(29) Wan Othman, W. N. N.; Liew, S. Y.; Khaw, K. Y.; Murugaiyah, V.; Litaudon, M.; Awang, K. Bioorg. Med. Chem. 2016, 24, 4464-4469.

(30) Kandiah, N.; Pai, M. C.; Senanarong, V.; Looi, I.; Ampil, E.; Park, K.W.; Karanam, A. K.; Christopher, S. Clin. Interv. Aging. 2017, 12, 697707.

Received November 12, 2018

Revised December 9, 2018

Accepted December 9, 2018 